Jurdimas (Jurnal Pengabdian Ke pada Masyarakat) Royal

Vol. 3 No. 2, Juli 2020, hlm. 123 - 128

DOI: https://doi.org/10.33330/jurdimas.v3i2.505

ISSN 2622-3813 (Online)

Available online at https://jurnal.stmikroyal.ac.id/index.php/jurdimas

\title{
PEMANFAATAN E-COMMERCE BAGI GENERASI MILENIAL
}

\author{
Nurul Rahmadani ${ }^{1^{*}}$, Masitah Handayani ${ }^{2}$, Rohminatin ${ }^{2}$, Pristiyanilicia Putri ${ }^{2}$ \\ ${ }^{1}$ Manajemen Informatika STMIK Royal Kisaran \\ ${ }^{2}$ Sistem Informasi STMIK Royal Kisaran \\ email: cloudyrara@gmail.com
}

\begin{abstract}
The growth of the e-commerce market in Indonesia is very high and is one of the largest in the world. As a country whose population is dominated by a mid-level economy, ecommerce is very positively welcomed by the Indonesian population, especially the millennial generation. The millennial generation is a generation of young people today who are currently in the age range of 15-34 years. This generation is the biggest consumer in utilizing the internet in many ways, such as social media and e-commerce. The method used in this service is a simulation using one e-commerce application, namely Shopee. The purpose of this Community Service activity is to utilize e-commerce, especially for millennials so that they can use it in positive terms. The result of this activity was the implementation of Community Service activities attended by 30 students at SMA Negeri 2 Tanjungbalai.
\end{abstract}

Keywords: e-commerce; millennial generation

Abstrak: Pertumbuhan pasar e-commerce di Indonesia sangat tinggi dan merupakan salah satu yang terbesar di dunia. Sebagai negara yang penduduknya didominasi oleh ekonomi tingkat menengah, e-commerce sangat disambut positif bagi penduduk Indonesia, terutama generasi milenial. Generasi milenial merupakan generarasi muda masa kini yang saat ini berusia dalam rentang usia15-34 tahun. Generasi ini merupakan konsumen terbesar dalam memanfaatkan internet dalam banyak hal, seperti sosial media maupun e-commerce. Metode yang digunakan dalam pengabdian ini ialah simulasi menggunakan salah satu aplikasi e-commerce, yaitu Shopee. Tujuan dilakukannya kegiatan Pengabdian Masyarakat ini adalah untuk memanfaatkan e-commerce terutama bagi generasi milenial sehingga dapat memanfaatkannya dalam hal positif. Hasil kegiatan ini ialah terlaksananya kegiatan Pengabdian Masyarakat yang dihadiri siswa-siswi SMA Negeri 2 Tanjungbalai sebanyak 30 orang.

Kata kunci: e-commerce; generasi milenial

\section{PENDAHULUAN}

Generasi milenial ialah generasi muda yang berusia kisaran 15 sampai 34 tahun (Naldo \& Satria, 2018). Generasi ini merupakan generasi awal yang banyak menghabiskan waktu di zona digital, sehingga teknologi informasi sangat mempengaruhi bagaimana cara generasi millenial hidup dan bekerja.
Generasi milenial merupakan generasi yang sangat banyak menggunakan internet dalam berbelanja online (Praharjo, 2019).

Kita telah memasuki era globalisasi, yaitu semua hal berbasis digital dan otomatis. Era ini merupakan tantangan bagi generasi milenial dalam menghadapi persaingan global (Ambarwati \& Sobari, 2020). 
Available online at https://jurnal.stmikroyal.ac.id/index.php/jurdimas

Kecenderungan generasi milenial saat ini ialah gemar bekerja ekspres dan segera mendapatkan umpan balik, pekerjaan juga maunya penuh tantangan karena fase kebosanan lebih tinggi dibanding generasi sebelumnya. Hal ini tantangan terbesar dikarenakan sifat pekerjaan tidak selalu begitu (Perspectives, 2019).

E-commerce merupakan jawaban akan tantangan bagi generasi milenial. $E$ commerce merupakan aplikasi belanja yang memudahkan pembeli untuk membeli barang sesuai kebutuhannya (Fauziyah, 2020). Namun, bagaimana para generasi milenial dapat memanfaatkan e-commerce sebaik mungkin dan dimohonkan dapat memajukan persaingan produk/jasa dari tingkat mikro sampai makro, serta dapat memasuki pasar global. Oleh karenanya pelatihan ini dipandang perlu dilakukan dengan tujuan untuk memberikan pengetahuan bagaimana memanfaatkan e-commerce bagi generasi milenial sehingga dapat diterapkan ke masyarakat.

\section{METODE}

Kegiatan Pengabdian Masyarakat ini mengambil judul Pemanfaatan $E$ commerce Bagi Generasi Milenial yang dilaksanakan pada tanggal 11 November 2019, yang dilaksanakan di SMA Negeri 2 Tanjungbalai. Peserta kegiatan adalah siswa-siswi SMA Negeri 2 Tanjung-balai yang diwakili sebanyak 30 siswa.

Metode yang digunakan adalah metode simulasi. Adapun langkahlangkah dalam pengabdian masyarakat dengan metode simulasi tersebut ialah dimana diawali dengan memberikan ceramah mengenai pemanfaatan $e$ commerce, kemudian dilakukan sesi diskusi serta tanya jawab mengenai pembahasan tersebut, setelah itu dilakukan simulasi dengan menggunakan salah satu aplikasi belanja online yaitu Shopee secara langsung dengan menggunakan laptop.

\section{PEMBAHASAN}

Pelaksanaan kegiatan pelatihan Pemanfaatan E-commerce bagi Milenial ini diawali dengan pem-bekalan materi yang meliputi, Pengenalan generasi milenial, Penge-nalan e-commerce, dan Simulasi praktek dengan menggunakan aplikasi e-commerce.

\section{Definisi Generasi Milenial}

Milenial yang juga disebut sebagai Generasi Y ialah golongan setelah Generasi X. Tak ada limit waktu yang jelas untuk awal dan penutup dari Generasi Y ini. Para pakar dan peneliti umumnya mendeskripsikan awal 1980-an sebagai permulaan kelahiran golongan ini hingga awal 2000-an sebagai penutup kelahiran. Milenial lazimnya ialah anakanak dari generasi Gen-X.

Milenial terkadang dikenal dengan sebutan "Echo Boomers" dikarenakan terdapat kenaikan tingkat kelahiran pada tahun 1980 sampai 1990. Untunglah di abad ke-20 tren mengarah ke keluarga yang lebih kecil di negara maju dan terus berkembang, sehingga akibat relatif dari "baby boom echo" biasanya tidak sebanyak dari penduduk setelah Perang Dunia II.

Karakteristik Milenial tidak sama, berlandaskan kondisi sosial dan ekonomi, serta wilayahnya. Akan tetapi, generasi ini dasarnya dilihat dari meningkatnya penggunaan teknologi digital, komunikasi, dan media (Naldo \& Satria, 2018). 
Jurdimas (Jurnal Pengabdian Kepada Masyarakat) Royal

Vol. 3 No. 2, Juli 2020, hlm. 123 - 128

Available online at https://jurnal.stmikroyal.ac.id/index.php/jurdimas

\section{Karakteristik Generasi Milenial}

Berdasarkan materi dari tulisan Hitss.com, diketahui terdapat beberapa jenis karakteristik generasi milenial yakni:

1. Memanfaatkan teknologi informasi;

2. Lebih percaya user-generated content dibanding informasi searah;

3. Lebih menyukai smartphone daripada televisi;

4. Wajib memiliki social media;

5. Biasanya tidak loyal namun bekerja efektif;

6. Kurang gemar membaca secara konservatif;

7. Lebih paham teknologi daripada orangtua mereka;

8. Condong bertransaksi secara cashless;

9. Condong lebih konsumtif dan malas; dan sebagainya (Hidayatullah et al., 2018)

\section{e-commerce}

Laudon dan Laudon (1998) mengartikan e-commerce sebagai: "The process of selling and buying goods electronically by consumers and from company to company through computerized business transaction". Dari definisi diatas, terdapat 3 poin utama terkait e-commerce yakni yang pertama terdapat proses penjualan dan pembelian via elektronik; kedua ialah terdapat konsumen ataupun peru-sahaan; dan terakhir jaringan kom-puter secara online dalam transaksi bisnis (Achjari, 2000).

$$
\text { E-commerce (Perdagangan }
$$

elektronik), ialah pengaplikasian jaringan komputer dan komunikasi dalam operasi bisnis. Pengertian e-commerce sendiri yaitu penggunaan internet dan komputer dengan browser web dalam memperkenalkan, mempromosikan, serta proses jual-beli produk.

Manfaat e-commerce, yaitu:

1. Dapat memiliki pasar inter-nasional;

2. Bisnis beroperasi tanpa harus terhalang oleh batas negara;

3. Anggaran dapat dihemat;

4. Proses jual-beli berlangsung cepat dan menekan resiko human-error;

5. Menekan pemakaian kertas dalam aktivitas, dimulai dari tahap desain, produksi, pengiriman, distribusi hingga marketing (Maulana, 2015).

\section{Komponen e-commerce}

Komponen yang dimiliki $e$ commerce adalah sebagai berikut :

1. Produk: Berbagai varian produk yang dapat dijual via internet, misalnya produk fashion, makanan, alat transportasi dan lainnya.

2. Tempat jualan produk: ialah browser web yang mempunyai domain dan hosting.

3. Metode pembayaran: Transfer via ATM, e-payment, COD, credit card, dan lainnya.

4. Metode pengiriman: jasa pengiriman barang (Pos Indonesia, JNE, J\&T, TIKI, dan lainnya) dan jasa antar dari ojek online.

5. Cara terima pesanan: e-mail, telepon, SMS, chatting, dan lainnya.

6. Pelayanan: email, Contact us, Telepon, Chatting, dan social media (Maulana, 2015).

\section{Jenis Kegiatan e-commerce}

\section{Pembelanjaan Online}

Toko on-line (virtual) dengan banyak varian ditokonya. Hal ini bertujuan menghemat biaya operasional toko fisik yang besar.

\section{Pembayaran Elektronik}

Sistem pembayaran ini berlaku untuk transfer belanja produk, 
Available online at https://jurnal.stmikroyal.ac.id/index.php/jurdimas

tagihan pulsa, tagihan internet, dan lainnya.

\section{Lelang Virtual}

Ini dipopulerkan oleh eBay untuk memudahkan jual-beli antar pembeli dan penjual dengan harga yang menguntungkan, dikarena-kan transaksi akan diproses setelah harga terbaik disetujui bersama.

\section{Transaksi Bank Digital}

Memudahkan masyarakat dalam melakukan aktivitas perbankan dengan cara on-line melalui aplikasi.

\section{Jual Beli Tiket Online}

Pembelian tiket transportasi seperti pesawat, bis maupun kereta termasuk dari kegiatan ini. Pembelian tiket menonton seperti pertandingan olahraga dan film juga termasuk.

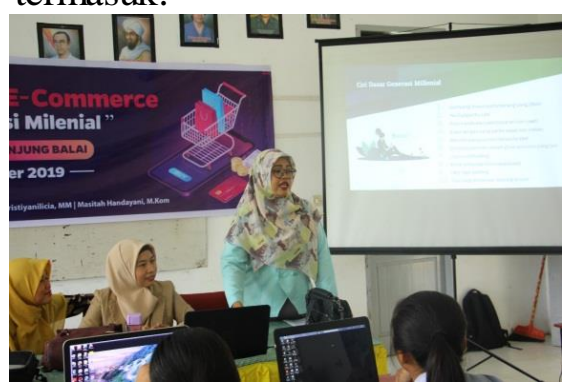

Gambar 1. Sesi Pemaparan Materi

\section{Aplikasi Shopee}

Shopee adalah aplikasi belanja on-line yang sukses di Indonesia karena telah memikat hati konsumen Indonesia dalam setahun setelah peluncurannya di 2015. Usaha Shopee untuk menembus pasar on-line Indonesia yakni dengan meraih penghargaan pada tahun 2017 untuk kategori kampanye pemasaran terbaik (Tribunbisnis, 2019). Shopee adalah perusahaan e-commerce dibawah asuhan Garena (sekarang menjelma jadi SEA Group), yakni perusahaan internet di Asia Tenggara. Shopee menggunakan teori Customer to Customer (C2C) yakni suatu teori penjualan dari konsumen ke konsumen akhir. Shopee memfasilitasi aplikasi on-line bagi penjual dan pembeli.

Shopee pertama kali dilkenal-kan di Singapura tahun 2015 dan merambat ke Malaysia, Filipina, Taiwan, Thailand, Vietnam, serta Indonesia. Adapun Visi Shopee: "Menjadi C2C Mobile Marketplace Nomor 1 di Asia Tenggara". Shopee saat ini dibawah bimbingan Chris Feng, sebagai CEO yang memfasilitasi penggunanya menjual maupun membeli produk melalui aplikasi Shopee baik dari platform iOS maupun Android (Praharjo, 2019).

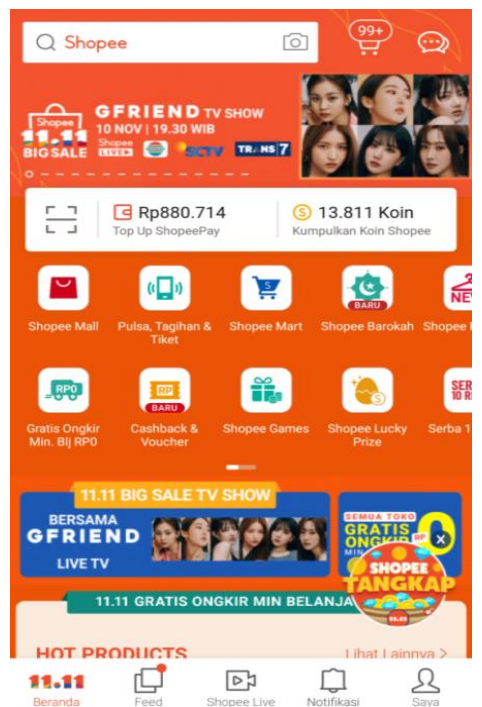

Gambar 2. Platform Shopee di Android

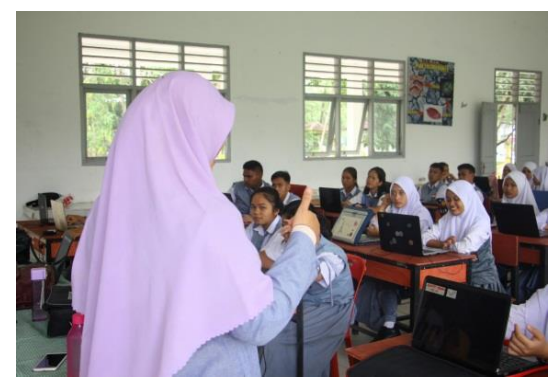

Gambar 3. Sesi Simulasi

\section{Fitur-Fitur Shopee}

\section{Gratis Ongkir}

Voucher ini bertujuan untuk menarik customer dari berbagai daerah dengan adanya potongan ongkos kirim untuk belanja. 
Jurdimas (Jurnal Pengabdian Kepada Masyarakat) Royal

Vol. 3 No. 2, Juli 2020, hlm. 123 - 128

DOI: https://doi.org/10.33330/jurdimas.v3i2.505

Available online at https://jurnal.stmikroyal.ac.id/index.php/jurdimas

VOUCHER GRATIS ONGKIR RPO

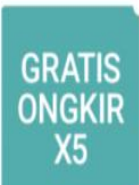

때텀 Min. Belanja

Mulai RpO

X5

Berlaku Hingga: 10.11.2019 S\&K

GRATIS

ONGKIR

$\mathrm{X}_{2}$

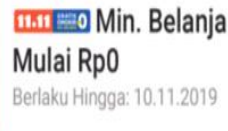

Gambar 4. Voucher Gratis Ongkir

\section{Cashback Belanja}

Fitur ini menarik customer karena mendapatkan cashback setiap berbelanja di Shopee.

VOUCHER CASHBACK SPESIAL.

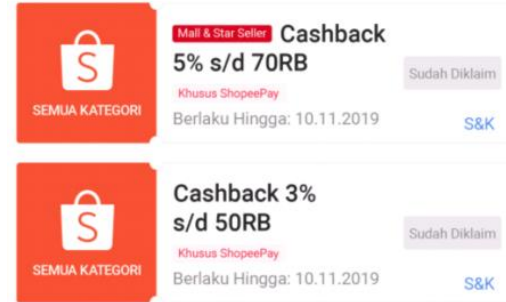

Gambar 5. Voucher Cashback

\section{Pembayaran Tagihan}

Fitur ini mempermudah dalam membeli pulsa, bayar tagihan listrik, air, telepon, internet, BPJS, bahkan dapat membeli tiket pesawat, bus, kereta api. Tidak hanya itu, setiap transaksi mendapatkan cashback yang masuk ke koin pengguna.

VOUCHER PULSA, TAGIHAN \& TIKET

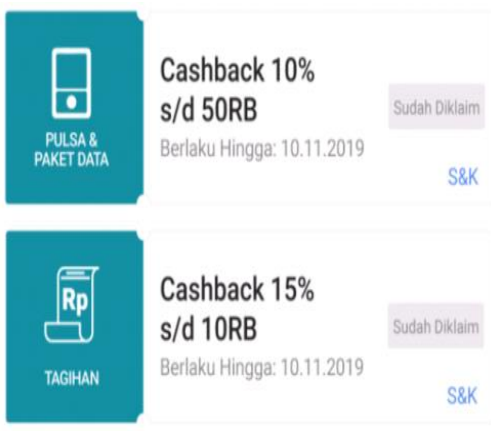

Gambar 6. Voucher Tagihan

\section{Games-Games Seru}

Selain semua fitur tersebut, masih ada fitur games yang menambah keseruan serta koin pengguna.

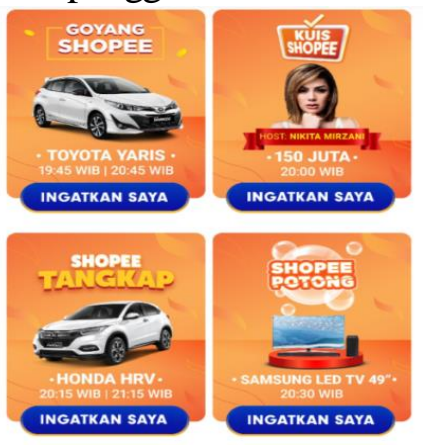

Gambar 7. Games Shopee

\section{Uang Digital}

Tidak perlu ribet dalam membayar belanjaan, karena Shopee juga menyediakan uang digital, yaitu ShopeePay.

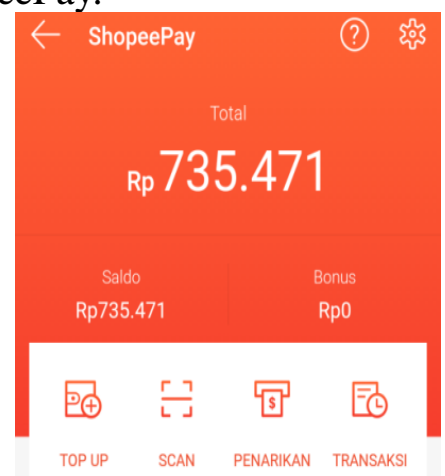

Gambar 8. Uang Digital ShopeePay

\section{SIMPULAN}

Hasil dari kegiatan Pengabdian kepada Masyarakat ini ialah siswa-siswi SMA Negeri 2 Tanjungbalai sebagai generasi milenial dapat menggunakan dan memanfaatkan e-commerce bukan hanya sebagai konsumen tetapi juga memajukan persaingan produk maupun jasa dari tingkat mikro sampai dengan makro, serta dapat memasuki pasar internasional. 
Jurdimas (Jurnal Pengabdian Kepada Masyarakat) Royal

Vol. 3 No. 2, Juli 2020, hlm. 123 - 128

Available online at https://jurnal.stmikroyal.ac.id/index.php/jurdimas

\section{DAFTAR PUSTAKA}

Achjari, D. (2000). Potensi Manfaat Dan Problem Di E-Commerce. Jurnal Ekonomi Dan Bisnis Indonesia, 15(3), 388-395.

Ambarwati, A., \& Sobari, I. S. (2020). Membangun Jiwa Kewirausahaan Di Era Milenial Bagi ahasiswa Institut Stiami Kampus Tangerang Selatan. Jurnal Komunitas: Jurnal Pengabdian Kepada Masyarakat, 2(2), 140-144. https://doi.org/10.31334/jks.v2i2.73 6

Fauziyah, M. A., Handayani, S., Program, E. E., \& Malang, U. N. (2020). Pengaruh Intensitas Pemanfaatan E-commerce Dan Tingkat Literasi Ekonomi Terhadap Tingkat Konsumsi Siswa Di SMA Negeri 4 Malang 1, 2. Jurnal Pendidikan Ekonomi, 13(1), 76-83.

Hidayatullah, S., Waris, A., \& Devianti, R. C. (2018). Perilaku Generasi Milenial dalam Menggunakan
Aplikasi Go-Food. Jurnal Manajemen Dan Kewirausahaan, 6(2), 240-249. https://doi.org/10.26905/jmdk.v6i2. 2560

Maulana, S. M., Susilo, H., \& Riyadi. (2015). Implementasi E-commerce Sebagai Media Penjualan Online. Jurnal Administrasi Bisnis, 29(1), 1-9.

Naldo, \& Satria, H. W. (2018). Studi Observasi terhadap Penggunaan Aplikasi LINE oleh Generasi Millenial. Jurnal Sosial Humaniora Terapan, 1(1), juli-desember.

Perspectives, D. I. (2019). Generasi Milenial dalam Bagi Sumber Daya Manusia Indonesia atau Ancaman. Generasi Milenial Dalam Industri 4.0: Berkah Bagi Sumber Daya Manusia Indonesia Atau Ancaman, edisi pertama September, 25-36.

Praharjo, A. (2019). Perilaku pembelian secara. Jurnal Manajemen Dan Bisnis MEDIA EKONOMI, 1999(1), 222-230. 